\title{
Impersonals and beyond in Slavic
}

\author{
Marguerite Guiraud-Weber \& Irina Kor Chahine \\ Aix-Marseille University / University of Nice - Sophia Antipolis, France
}

This book grew out of the selection of papers presented during the 6th Annual Meeting of the Slavic Linguistics Society (2011, Aix-en-Provence, France). The Meetings of the SLS include presentations in both theoretical and applied approaches, and in keeping with this tradition in this volume we have provided equal consideration to various issues of Slavic linguistics, from morphology to syntax and semantics.

While the papers collected in this volume attempt to throw light on various aspects of Slavic linguistics, often from a typological point of view, most of them have an underlying common subject, namely expression of the impersonal. Far from being a marginal phenomenon, the means of expressing the impersonal is one of the main issues in Slavic languages. This topic is also closely related to other questions discussed in this volume, such as zero sign, passive voice, and lexis. For this reason, although they are inevitably grouped into several chapters, most articles often discuss issues that are partially related to each other.

The issue of the impersonal can be considered in a variety of ways, i.e. it may refer to grammatical person, verbal syntax, or voice usage. An extensive bibliography has been developed on this question. Impersonal constructions constitute only a part of this vast domain. We know that these constructions exist to some extent in various languages. In some languages, such as Arabic, Persian, or Japanese, they are relatively rare, while in others, like Slavic languages, they turn out to be especially abundant. However, even in the Slavic languages this domain is varied. Among five Slavic languages belonging to three different groups, namely Russian, Polish, Czech, Serbo-Croatian, ${ }^{1}$ and Bulgarian, it is in Russian that the system of impersonal constructions is most developed. These constructions exist to a lesser extent in other Slavic languages. It should be noted that the development of impersonal constructions does not always appear to be a result of geographical language contact. Nonetheless, it is necessary to conduct further research to establish a detailed typology of impersonal constructions in the Slavic languages. 1.

\footnotetext{
${ }^{1}$ Here we do not make a distinction between Serbian and Croatian.
} 
Impersonal constructions have been well known since antiquity; in particular they are well attested in Greek and Latin. In modern European languages, among non-referential markers of impersonal constructions we can point out it in English (it's raining), es in German (es regnet), or even the non-referential il in French (il pleut) and .a in colloquial French (.a tonne) (Maillard 1985). Often used to express meteorological phenomena or sensations (cf. Malchukov \& Siewierska 2011), these constructions are based on verbal syntax that allows either a personal reading, or an impersonal one, depending on context (je me souviens.../il me souvient...). In Slavic languages, the domain of impersonal constructions is probably the richest in comparison to other European languages. Impersonal constructions in Slavic languages are very common and include various syntactic models with a large range of semantics, including expressing existence, sensations, physical or mental states, object of communication, and modality. Moreover, these constructions cannot be considered exclusively in the context of verbal syntax, because the core predicate can be expressed not only by a verb, but also by a predicative form (noun or adverb serving as a predicate), or even by the entire construction.

Below we will briefly discuss general issues associated with impersonal constructions in Slavic languages and will present an overview of this vast domain in order to provide a necessary context for this collection of papers. Moreover, the topic of the impersonal will allow us to consider by extension other issues covered in this volume. It's worth mentioning that articles included in this volume on Slavic languages contribute to the discussion about impersonal and related constructions recently compiled by Andrej Malchukov and Anna Siewierska and edited in 2011 by John Benjamins, which concerns a wide range of languages and linguistic families.

\section{Impersonal sentences: A problem of definition}

Impersonal sentences are attested in all Slavic languages, although their variants do not appear in every language, and their frequency is not the same in different languages. Therefore, it is a heterogeneous domain, despite the fact that they originated from the same archaic Balto-Slavic model derived from the IndoEuropean one. Their heterogeneity and diversity have been examined in multiple studies devoted to this issue; however, Slavic impersonal sentences have not yet received a completely exhaustive description.

Diachronic studies have brought to light a variety of ways the impersonal sentences have evolved in each language. Historical data show that very often an identical or quasi-identical structure in two different languages is not necessarily the same linguistic phenomenon, and that visible resemblances may be misleading. 
It is therefore necessary to acknowledge that the role an impersonal construction plays in the system of one language may not be the same that it plays in another. This represents a serious difficulty for potential comparison between languages.

Another difficulty concerns terminology. The term impersonal refers to various syntactic constructions, and, according to the linguistic schools and traditions in each country, is used differently. As early as in 1883 Franz Miklosich introduced the term of "subjectlose S.tze" to underline the absence of subject as a common property of these sentences, and since then, this term has known some development, in particular in the Czech and Polish schools. However, when referring to the notion of "sentences without a subject," we have to know what subject is, because this notion is not always clearly defined and remains implicit in many studies. An attempt to provide further clarification consists in talking of sentences without the nominative case, since nominative is typically the case of the subject (Wolińska 1978; GuiraudWeber 1984). However, this formulation is not entirely satisfactory either. It should be indeed clarified that although the nominative is certainly the standard case for grammatical subject, it can also play other syntactic roles. Despite the inconvenience of the term impersonal, it has finally become accepted and universally recognized; in particular within studies written in Russian and English. It should be noted, however, that this is a purely conventional term, and many scholars have shown its inadequacy (Zolotova 1973; Creissels 1991; Malchukov \& Siewierska 2011, and others).

\section{The issue of subject}

The conventional term of impersonal sentence is now used, on the one hand, merely as a label applying to all sentences that do not conform to the basic pattern of subject in nominative + agreed predicate; on the other hand, it is used in a narrow sense for designating sentences that we would call purely impersonal, and which we cannot classify according to morphological properties of the predicate alone, as was proposed in Galkina-Fedoruk 1958 (and by other scholars pursuing this tradition), but according to syntactic and semantic properties of impersonal sentences as a particular syntactic structure. In this structure, in addition to the predicate, there is very often a recurring nominal element in an oblique case. The latter refers to the object or person concerned by the events designated by the predicate. And in this case, the non-agreed predicate takes the form of 3rd person of singular in present or the form of neuter then it is in past tense. It is possible to show that the strictly impersonal sentence, regardless of the variant it represents, always excludes controlled action by an animate agent. Thus, the lack of nominative, which is the 
only case appropriate for designating voluntary action by an animate agent, is semantically justified. If the events designated by the predicate refer to a person, the person will be expressed by an oblique case and play the role of a simple observer, a passive participant, or, at best, an experiencer, but never of an active agent.

It has long been observed that some oblique cases in impersonal sentences behave similarly to a nominative subject. This is especially the case for dative (type (1a)) (cf. Say, this volume), to a lesser extent for accusative (type (1b)), and even for instrumental (type (1c)) (cf. Schlund, this volume).

(1) Russian
a. Mne dušno.
I:dat suffocate:pred
'I'm suffocating.'
b. Menja znobit.
I:acc chilly:prs.3sg
'I feel chilly.'
c. Vetrom sorvalo kryšu.
wind:inst tore-off:neut roof:acc
'The wind tore off the roof.'

These similarities are at the origin of a new term in Russian linguistics, namely sub"ekt ("semantic or logical subject"), which is opposed to podležaščee (grammatical subject). The frequency of these terms in Russian linguistics used in all Russian textbooks and papers shows the importance of this phenomenon in the Russian language, which explains why some linguists attempt to describe syntax in semantic rather than in formal terms (Zolotova 1973).

Studies devoted to the notion of subject in different world languages, in particular those by Edward Keenan (1976) and Bernard Comrie (1981), have shown that there is a certain number of morphological, syntactic, and semantic proprieties that allows for identifying the subject. These features are not the same in all languages, but can be similar. If, in the case of Russian, we temporarily renounce to define the subject in discrete terms (as an argument that agrees with the verb in number, person and gender), it becomes apparent that certain subject properties (such as indespensability, control over the reflexive pronouns, position in front of the predicate, topic of the sentence) not only characterize the subject in nominative, but can occur in other oblique cases, in which case the latter play the role of the argument enabling the predicate quality. This approach requires a scalar definition of the subject, such as some arguments will be considered more "subject" than others and will be placed closer to the nominative in a subjectival scale. From this point of view, it becomes possible to justify the linguistic insight that underlies the 
sub"ekt/podležaščee dichotomy. This approach has been adopted for Russian in Testelec 2001 and Guiraud-Weber 2003. It supports preferential treatment of certain nominal arguments in oblique cases within impersonal sentences because these arguments express the quality of the predicate.

However, only Nominative (or its syntactic equivalents) can be considered as grammatical subject in Slavic. The choice of other cases is determined by general semantics of the sentence. Thus, on examples from Slavic languages we can see that Genitive indicates the absence or non-existence; Dative, and sometimes Accusative case, designates physical and mental state; Instrumental characterizes the inanimate destructive force, and Locative - a space. In addition, the two latter cases can be used with prepositions to designate other specific situations (Guiraud-Weber 1984). This fact shows that not only the lexis, but also the syntactic structure takes part in forming the meaning of the sentence.

\section{Evolution of impersonal sentences in Russian and across other Slavic languages}

The domain of impersonal sentences in Russian is very broad, especially in comparison to other Slavic languages. Over many centuries it has continued to become richer. Historical studies have demonstrated the following trends:

1. Expansion of the negative existential sentences (see (2a)). Studies by N. Ju. Švedova have shown that lexical means of predicates in these constructions have been continually renewed ever since the 18th century (Švedova 1964). This expansion, involving a great number of verbs in modern Russian, is described in a number of publications (Ickovič 1974; Babby 1980; Padučeva 1992; Partee \& Borschev 2007; Guiraud-Weber 2003);

2. Emergence, at the end of 19th century, of constructions with the nominal argument "s + instrumental" (see (2b)), obviously related to the deletion of the desemantized subject, like delo 'fact', položenie 'situation', vopros 'question' (Zolotova 1966);

3. Decline of passive impersonal constructions and their substitution with impersonal constructions using the nominal constituent "o + locative" (see (2c)) (Švedova 1964);

4. Lexical and syntactic reorganization of constructions with dative argument (see (3c-d)), which since the 19th century has had the semantic function of experiencer replacing the construction "dlja + genitive" (see (3a-b)). During the 19 th century, serious confusion prevailed in this domain, and variant with dlja are not any more attested in today's Russian (Švedova 1964). 
(2) a. Ego ne vidno.

he:acc neg visible:pred

'He is not visible.'
b. $S$
$\begin{array}{llll}S & \text { den'gami } & \text { bylo } & \text { ploxo. } \\ \text { with } & \text { money:inst } & \text { was:aux.neut } & \text { tight:pred }\end{array}$

'Money was tight.'
$\begin{array}{llll}\text { c. } O b \quad \text { ètom govorilos' } & v & \text { gazetax. }\end{array}$
about this:loc discussed:neut.ref in newspapers:loc

'This was discussed in the newspapers.'

(3) a. Dlja nego kazalos' strannym

for he:gen seemed:neut strange:inst

'It seemed strange to him.'

$\begin{array}{clll}\text { b. Dlja } & \text { nego bylo } & \text { prijatno } & \text { videt' }^{\prime} \\ \text { for } & \text { he:gen was:aux.neut } & \text { nice:pred } & \text { see:inf }\end{array}$

'It was nice for him to see.'
c. Emu kazalos' strannym
he:dat seemed:neut strange:inst
'It seemed strange to him.'
d. Emu bylo prijatno videt'.
he:dat was:aux.neut nice:pred see:inf
'It was nice for him to see.'

In West Slavic languages, in particular in Polish and Czech, the domain of strictly impersonal sentences appears to be less extensive; while constructions with indefinite human subjects - "man-constructions" - are abundant and diverse. In South Slavic languages, like in Serbo-Croatian, the domain of impersonal sentences is more limited, and it is especially restricted in Bulgarian because of the absence of noun declension. What follows is a brief survey of the main types of impersonal sentences in Slavic languages.

Impersonal sentences describing environment exist in all Slavic languages:

$\begin{array}{ccc}\text { (4) a. Ru. } N a \quad \text { ulice } & \text { xolodno. } \\ \text { in } \quad \text { street:loc } & \text { cold:pred } \\ \text { 'It's cold outside.' } & \end{array}$

b. Bg. Dušno.

stuffy:pred

'It's stuffy.'
c. S-Cr. Smrklo se.
grown-dark:neut ref
'It has grown dark.'

They regularly occur without any nominal support, but necessarily refer to a space, often where the speaker is located (according to deictic rules). In such impersonal 
sentences, the situations are always localizable, unlike non-localizable situations depicting feelings, emotions, beliefs, or psychical states of individuals (cf. Boguslavskij 1991). Thus, in this type of impersonal sentence, the nominal element referring to location is not just an adverbial phrase which, by definition, could be deleted. It semantically represents necessary support to the predicate, without which there would be no message. S. Say (this volume) addresses in part the relation of these predicatives referring to location, which he considers to be "objective", with predicatives that are more likely to use dative, and which he considers "subjective" (i.e. (5)). The first type of sentences is usually accounted for as "meteorological phenomena" (cf. Galkina-Fedoruk 1958; Birjulin 1994) even though it also comprises sentences like $(6 a-b)$ have nothing to do with weather events. They simply describe the space concerned by the conversation, like construction (6c) where the space is characterized from the olfactory perspective. Thus the latter construction should also be included in this category (Guiraud- Weber 1979).

$$
\begin{aligned}
& \text { (5) Emu xolodno. } \\
& \text { he:dat cold:pred } \\
& \text { 'He is cold.' }
\end{aligned}
$$

(6) a. $V$ komnate pusto. in room:loc empty:pred

'The room is empty.'
b. Na lestnice tixo.
on stairway:loc quiet:pred
'The stairway is quiet.'
$\begin{array}{cll}\text { c. } V \text { komnate } & \text { paxnet } & \text { jablokami. } \\ \text { in room:loc } & \text { smell:prs.3sg apples:inst }\end{array}$
'It smells like apples in the room.'

Sentences of negative existence are extremely frequent in Russian (see (7) below) and involve a large number of verbs, including verbs that are not traditionally perceived as verbs of existence (vyjti 'to go out', projti 'to pass though', vypast' 'to fall', rasti 'to grow', etc.). In Polish, genitive may occur only in the existential sentences with the verbs być and zostać (both of which also function as auxiliary verbs). The verb 'to be' contains two forms: być and mieć, functioning in complementary distribution $(8 \mathrm{a}, \mathrm{b})$. No other verb can serve as a predicate of existence. However, unlike Russian, Polish generalizes the usage of genitive for the direct object under negation, which is used in all circumstances and is even extended to adverbial modifier in colloquial Polish (8c, d) (Guiraud-Weber 2003; Guiraud-Weber \& Zaremba 2007). In Serbo-Croatian, existential sentences use genitive when the sentence is negative but have a tendency to use this case in affirmative sentences as well $(9 \mathrm{a}, \mathrm{b})$. However this construction is only limited to one single verb of existence represented by forms of the verbs imati - biti, used in 
complementary distribution like in Polish: the verb imati 'to have' is used in present tense, and biti 'to be' in other verbal forms $(9 c, d)$. In contrast, in Czech, sentences of negative existence have disappeared. Their decline began in the 17th century, and is now complete (Hausenblas 1958). Even negative sentences with the verb 'to be' use nominative in Czech (10) (Žaža 1978).

(7) Russian Otca ne bylo doma.

father:gen neg was:neut at-home

'The father was not at home.'

(8) Polish
a. Jest / byt
chleb
is:3sg / was:3sg.m
bread:nom.m
'There is/was some bread.'
b. Nie ma /nie było chleba
neg have:prs.3sg / neg was:neut bread:gen
'There is/was no bread.'
c. Nie chce zupy
neg want:prs.1sg soup:gen
'I do not want soup.'
d. Nie pracowalem calej nocy
neg worked:1sg all:gen night:gen
'I did not work all night.'

(9) Serbo-Croatian
a. Nema
knjige.
have:3sg.neg book:gen
'There is no book.'
b. Ima knjige / knjiga.
have:3sg book:gen / book:nom.f
'There is a book.'
c. Nema ga
have:prs.3sg.neg he:gen
'He is not here.'
d. Nije bilo knjige
neg was:neut book:gen
'There was no book.'
(10) Czech Otec nebyl doma
father:nom.m was:3sg.m.neg at-home
'The father was not at home.'

All Slavic languages use the dative case for experiencer with predicates describing a person's physical or mental state (1a), (5), (11a-d): 


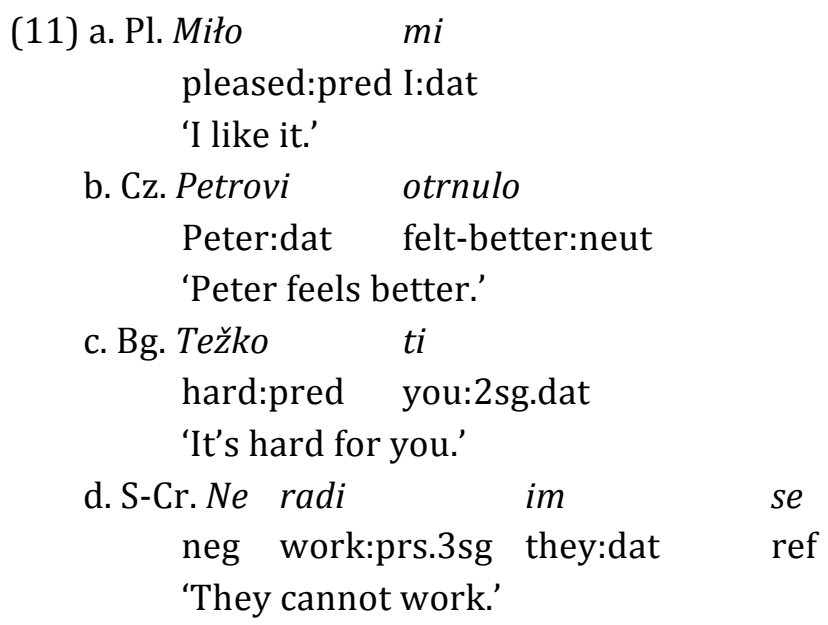

In West Slavic languages, most impersonal constructions with modal predicate (such as Russian (12a-b)) have been replaced by personal constructions with loantranslations from German müssen, dürfen, and haben. Thus the Czech verbs muset, smĕt, and mít, like their Polish counterparts musieć and mieć, require a nominative subject (Wolińska 1978; Weiss 1987, 1988; Žaža 1998).

(12) Russian
a. Mne nado rabotat'
I:dat need:pred work:inf
'I need to work.'
b. Emu nel'zja kurit'
he:dat should-not:pred smoke:inf
'He should not smoke.'

Russian negative constructions, such as (13a), with a dative experiencer and a negative predicative construction are also present in Bulgarian (13b). In Czech, this construction appears both in negative and affirmative forms (13c) (Mrázek 1990; Žaža 2002), which is also the case in Serbo-Croatian (13d, e). Polish, however, does not have similar constructions.

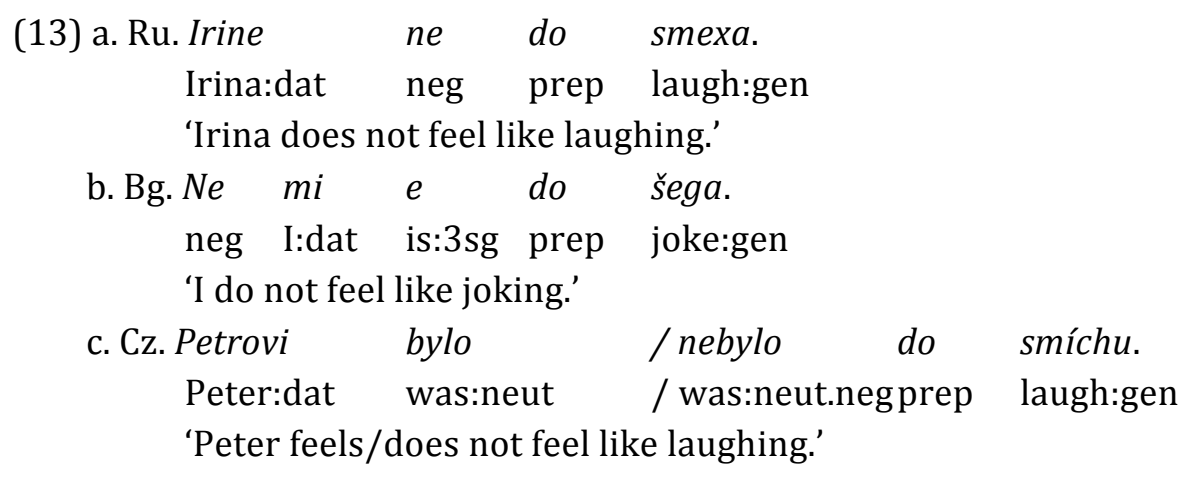




$$
\begin{aligned}
& \text { d. S-Cr. Irini je do smeha. } \\
& \text { Irina:dat is:3sg prep laugh:gen } \\
& \text { 'Irina feels like laughing.' } \\
& \text { e. S-Cr. Nije Irini do smeha. } \\
& \text { is:negIrina:dat prep laugh:gen } \\
& \text { 'Irina does not feel like laughing.' }
\end{aligned}
$$

Other types of impersonal sentences with a dative experiencer are "lacking" in West Slavic languages. Originally occurring in Old Slavic, Russian infinitive sentences like (14a, b), are frequent nowadays (Veyrenc 1979; Maurice 1996; Fortuin 2000), but as shown by A. Israeli (this volume), who offers a detailed and well illustrated study of infinitive constructions in Russian, their usage remains syntactically and stylistically limited.

(14) Russian
a. Emu $\quad$ xodit'.
he:dat play:inf
'It is his turn (to play).'
b. Vam ne ponjat'.
you:2pl.dat neg understand:inf
'You will not be able to understand.'

The dative plus infinitive construction is neither common nor productive in other Slavic languages. Only some relics of it remain in Polish (Wolińska 1978; Weiss 1993) and in Serbo-Croatian (Vojvodić 2007) while it seems to have completely disappeared in Czech (Žaža 1998). Thus, there is an obvious disparity between impersonal sentences with a dative experiencer that are widely used in Slavic languages on the one hand, and, on the other hand, infinitive impersonal sentences with dative attested only in some Slavic languages. The two constructions also present functional differences. This leads some scholars to suggest that these constructions contain two different types of dative "resulting from distinct casemarking strategies" (Franks 1995). In this volume, S. Say suggests some possible origins of the dative constituent with Russian predicatives (adverbial predicate). On the basis of semantic relationship between these predicatives and the argument structure of the corresponding short and long adjectives, he shows that they represent a heterogeneous class of elements and distinguishes three possible strategies.

Unlike the dative experiencer discussed earlier, the accusative argument is much less common in impersonal sentences in Slavic languages. This construction appears in Russian with a limited number of verbs (15a-b). The accusative argument should not be confused with a direct object in accusative because the impersonal 
sentence uses an intransitive verb (15c-d). This type of accusative is thus an argument of an intransitive verb. In contrast, in the construction (17a) below, the accusative kryšu is a regular direct object of the transitive verb sorvat'. The construction with the accusative occurs with a much more limited number of predicates in other Slavic languages (16):

(15) Russian
a. Ego
lixoradit.
he:acc tremble:prs.3sg
'He has a fever.'
b. Eë peredërnulo.
she:acc shuddered:neut
'She shuddered.'
c. *Ja ego tošnju.
I:nomhe:acc make-sick:prs.1sg
Intended: '*I make him sick.'
d. ${ }^{*} O n \quad e \ddot{e}$ peredërnul.
he:nom she:acc shuddered:3sg.m
Intended: '*He shuddered her.'

(16) a. Pl. Poderwało

shuddered:neut he:acc

'He shuddered.'
b. S-Cr.Strah vas bilo.
scary:pred you:2pl.acc was:aux.neut
'It was scary.'
c. Bg. Trese me.
tremble:prs.3sg I:acc
'I am trembling (from fever).'

Russian constructions with the instrumental case depicting damage caused by a natural phenomenon or an unknown force (17a-b) have a corresponding construction without instrumental in West Slavic languages (18a-b, 19a-b).

(17) Russian

a. Vetrom sorvalo kryšu

wind:inst tore.off:neut roof:acc

'The wind tore off the roof.'

b. Ego ranilo oskolkom

he:acc wounded:neut shrapnel:inst

'He was wounded by shrapnel.' 
(18) Polish

a. Zasypało drogę. covered:neut road:acc

'The road was covered.'

b. Zalało pole.

flooded:neut field:acc

'The field was flooded.'

(19) Czech

a. Bratra zabilo.

brother:acc killed:neut

'My brother was killed.'

b. Souseda ranilo.

neighbor:acc injured:neut

'The neighbor was injured.'

According to most scholars of comparative Slavic studies, the "impersonal" instrumental, which is used, as we know, for a meteorological phenomenon or a force endowed with its own energy, takes a central place in East Slavic languages, in particular in Russian, but it has a rather peripheral status in other Slavic languages (Mrázek 1964; Ivić 1965). From the structural point of view, we can refer to R. Mrázek, who was aware of the specificity of the "impersonal" instrumental and its structurally indispensability, and compared it to a subject (Mrázek 1964), although this form should be placed at the far end of the subjectival scale (see above, § 2). On the other hand, from the typological point of view, it is possible to compare these models to ergative constructions that assign an oblique case to the subject of transitive verbs. Thus, K. Schlund (this volume) attempts to show the origin of Slavic instrumental constructions using formal, semantic, and pragmatic markers that make them similar to ergative constructions ${ }^{2}$ (in particular the example of Hindi is used), and discusses a possible correlation between the emergence of impersonal sentences in Slavic and the grammaticalization of the verb 'to have'. Finally, since the neutralization of the role of agent is proper not only to ergative and impersonal but also to passive constructions we will return to this issue later (see $\S 5$ ).

\footnotetext{
${ }^{2}$ Another paper in this volume presents a comparative study between Slavic (accusative) languages and ergative languages (cf. Janic, this volume).
} 


\section{Impersonal and indefinite subject}

It is worth mentioning another problem related to identifying impersonal constructions. In order to identify strictly impersonal sentences, we must eliminate all instances when the subject is missing due to the influence of context or pragmatic, lexical, and stylistic constraints, i.e. all elliptical or deleted subjects. The cases of zero subject must be eliminated as well. The ellipsis and zero subject always denote a significant absence. The elliptical subject may however be reinstated, which is not possible for zero subject: no lexeme can substitute a zero subject without changing the meaning of the sentence. Among sentences without a nominative subject, i.e. impersonal sentences "in a large sense," are those types which refer to a generic or indeterminate subject. These sentences have different characteristics in each Slavic language, and their typology is yet to be examined.

In Russian there are two well-known variants of such sentences: one with zero subject, designating a person or a group of indeterminate persons, in principle excluding the speaker (20); and one referring to a "universal person," which can include the speaker (21).
(20) $\mathrm{Na}$ zavode
bastovali
at factory:loc striked:3pl
'There was a strike at the factory.'
(21) Ego ne provedëš
he:acc neg trick:prs.2sg
'He can't be fooled.'

Both constructions, unlike impersonal sentences in a narrow sense, generally include an action verb. They also have a very real, although indeterminate, agent. They contain different forms of verbal predicates: while the impersonal sentence strictly speaking has a predicate in the 3rd person singular, which can be considered a mark of non-agreement, in sentences with zero subject, the verb is in the 3rd person plural (for the first type) or in the 2nd person singular (for the second type) Constructions of the first type occur in most Slavic languages, notably in Bulgarian, Polish and Czech. As for the second type of constructions, with the exception of Russian, most other languages express the generic human subject with a word etymologically related to the lexeme 'man' (such as Man in German or on in French) (pl. człowiek, bg. čovek, cz. člověk, s.-cr. čovjek): pl. Człowiek nie wie co ma robić 'One does not know what to do'; bg. Čovek ne znae nikoga kakvo može da se sluči 'You never know what might happen'. However, these Slavic constructions are personal. 
A third variant of zero subject, which is not always mentioned in descriptions of Russian or is confused with strictly impersonal sentences, may be added to the two types presented above, cf.

(22) Russian
a.Pod krovat'ju zaševelilos'.
under bed:inst moved:neut
'Something moved under the bed.'
b. Nad golovoj gudelo.
over head:inst buzzed:neut
'Something buzzed over his head.'

Its specificity has been noted by V.L.Georgieva (Georgieva 1969, 1978). Indeed, the zero subject in these sentences can either refer to a person or to an animal, as well as to an indefinite object. In other words, it does not necessarily refer to a person, and its predicate is in the 3rd person singular. One can observe a certain correspondence of such sentences with the constructions existing in other Slavic languages that also use a verb in the 3rd person singular without an explicit subject, but in this case the zero subject refers to a person (not to an inanimate object), and very often to the speaker (23-24). Such constructions always use a reflexive verb (cf. Krzek, this volume; see also reflexive constructions below, §5).

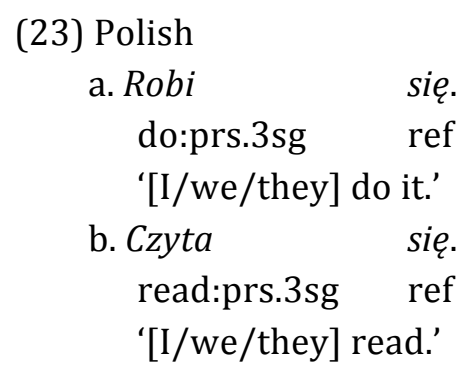

(24) Serbo-Croatian
a. Ide se.
walk:prs.3sg ref
'[I/we/they] walk.'
b. Govorilo se.
talked:neut ref
'[I/we/they] talk.'

It is precisely these forms of indefinite subject that have not been lexicalized in Slavic languages (Russian, Polish, and Czech) that D. Weiss (this volume) discusses in a broader context of what he calls "syntactic emptiness", which includes the

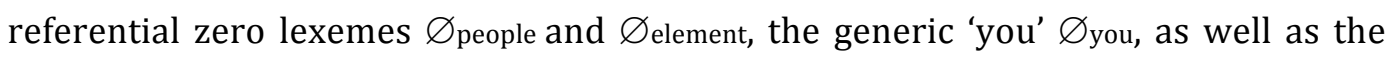
zero copula and omission of verbs of action. Based on diachronic data and placed in a typological perspective, his conclusions on the phenomena 
of "syntactic emptiness" observed in colloquial Russian are in accordance with the Eurasian orientation of the latter.

\section{Impersonal and related constructions}

The absence of agent or its occasionally minor status makes impersonal sentences closer to other models that share some of their features. This often makes identifying these constructions difficult. J. Milićević (this volume) discusses this very issue. Through the theoretical background of the model "Meaning $\Leftrightarrow$ Text", she describes morphological mechanisms, such as diathesis and verbal derivation that operate within different constructions without a subject in Serbian as compared to other Slavic and European languages. She notes that impersonal constructions often appear as a result of these morphosyntactic transformations.

While similarities between impersonal and passive constructions can be observed on the synchronic level, they can be seen on the diachronic level as well. In the history of Slavic languages, the development of impersonal sentences is often related to passive constructions. Thus, in Polish, the passive suffix -no/-to became an impersonal marker (Pisarkowa 1984), which can be found in sentences like (25), with a direct object making the passive reading impossible. Today, they function as active constructions (cf. Krzek this volume).

\section{(25) Podano herbate. served:part.neut tea:acc 'Tea was served.'}

Similarly, in Russian, the relatively late emergence of impersonal constructions with instrumental, such as (17a) may have originated from the expansion of the instrumental agent in passive constructions. In Old Russian, the agent was expressed by the form "ot + genitive," which subsequently became outdated and fell out of use (Ivić 1965). It is interesting to note that in similar modern Serbo-Croatian structures the "real" passive construction is used: an inanimate agent is encoded by the instrumental (26a), while an animate agent is encoded by the phrase "od + genitive" (26b).

(26) Serbo-Croatian
a. Put
je zatrpan
snegom.
road:nom.m
be:3sg covered:part.m
snow:inst
'The road is covered with snow.'
b. On je odlikovan od predsednika. he:nom be:3sg awarded:part.m by president:gen
'He was awarded by the president.' 
Furthermore, there are similarities between passive constructions and sentences with "o + locative", such as (27), which replaced the former impersonal passive (see $\S 3$ above) (Švedova 1964).

(27) $O b$ ètom govorilos' $\quad v \quad$ gazetax.

about this:loc discussed:neut.ref in newspapers:loc

'This was discussed in the newspapers.'

The classification of these constructions among impersonal sentences is not always unanimous. In this construction, the postfix -sja attached to a verb can be seen as a morphological marker of impersonal subject originating from a verbal derivation, which is often confused with the process of passivization (see various types of passive constructions in Plungjan 2003).

In addition to these examples of direct links between the impersonals and passive, it should be noted that the domain of impersonal constructions has been gradually expanding at the expense of the passive. Thus, in Russian, in sentences with a predicate in the 3rd person plural, the role of the agent is minimal (zero subject), which makes them closer to passive constructions where the agent plays a peripheral role. Some scholars think that this construction compensates for an absent position in the passive paradigm, which does not possess all aspect and tense forms (Wiemer 1996). Besides, it is also possible to view impersonal sentences as a type of construction where the voice opposition is neutralized.

On the other hand, the relationship between impersonal and reflexive constructions is based on operations that affect the predicate-argument structure. From a certain point of view, this operation, which detransitivizes a transitive construction, can be linked to the phenomenon observed in ergative languages where this type of construction contains a "dedicative anti-passive marker." It is in this context that K. Janic (this volume) proposes analyzing Slavic reflexive morphemes, namely ru. -sja, pl. sie, and s-cr. se. Despite the fact that these reflexive morphemes appear in constructions with varied semantics (impersonal, passive, reflexive, reciprocal), M. Marelj and E. Reuland present a formal, unified analysis of these morphemes, which allows them to derive their pure-reflexive and nearreflexive readings and to point out the differences between South/West Slavic languages, which have developed a system of clitics, and East Slavic languages where the reflexive morpheme is realized only as the verbal affix-sja. It is also using the formal properties of reflexive items in various languages (ru. sebja, drug druga, pl. siebie, cz. sebe, bg. sebe si, en. himself, each other...) that S. Franks (this volume) shows what is relevant for "binding" in the morphological structure of these anaphors. Finally, A. Zimmerling compares syntactic properties of Slavic possessive clitics (i.e. ru. sebe, bg. $m i$ ) with syntactic properties of possessive constructions (e.g. ru. u X-a est' Y) in terms of syntactic operation described as Possessor Raising, and 
concludes that this concept is not really applicable to Slavic languages for which the term Possessive Shift seems to be more appropriate.

\section{The role of lexis}

Studies of Slavic impersonal constructions allow us to measure to which point syntactic structures are dependent on lexis, since most constraints and limitations in syntax are realized through the lexicon. For this reason, studies on lexis still remain an important part of research, and our discussion has left a special place for them.

\subsection{Interaction between lexis and grammar}

Besides lexical meaning in impersonal constructions (see especially the article by S.Say) and lexical issues marginally touched upon in most publications, the interaction between lexis and grammar is a focal point of interest for certain authors.

The first is a comparative study on evidentiality in Macedonian and Albanian. Mainly related to the lexical domain in Slavic languages (ru. jakoby, mol, pl. ponoć, jakoby, cz. prý/prej, mac. navodno...), the category of evidentiality in Macedonian possesses additional grammatical resources, in particular, it uses forms of the verbal perfect which presents a problem of interpreting homonymous forms (evidential versus perfect). Thus, M. Makartsev (this volume) attempts to analyze mechanisms for decoding the meaning of utterances using materials of simultaneous translation of political discourse in both languages. Strategies used in political discourse also take into account lexical choice, which will be discussed below (cf. article by D. Dobrovol'skij \& L. Pöppel).

The interaction between lexis and grammar is also observed in deverbal nouns. The question posed by G. de Valdivia, J. Castellv. and M. Taul. (this volume) is whether the aspect of the verb (imperfective/perfective) at the origin of Russian deverbal nouns (such as formirovanie 'formation', zakaz 'order') has any impact on the lexical aspect of the latter (i.e. event, result, or state). Using an experimental framework and statistical data, the authors reexamine this question and show that the verbal aspect cannot be viewed as a determinant in lexical denotation of deverbal nouns, although it makes an important contribution to it.

Furthermore, in this section we can also consider cases of lexical desemantization in favor of a particular grammatical function. Thus, it has been shown that in many languages verbs of motion and position regularly undergo this kind of semantic shift (Majsak 2005). Confirming this fact in Polish data, D. Sikora offers a detailed analysis of the Polish verb iść 'to go', which is currently used as a true auxiliary. 
To a certain extent, the interaction between lexis and grammar also concerns the usage of conjunctions: these items have their own semantics, but their usage is impossible without the grammatical constructions in which they appear. A. Letuchiy (this volume) discusses this issue in his study on tripartite constructions with the lexemes čtoby and kogda, and points out a particular verbal agreement (past tense in the temporal clause), which is not mentioned in Russian grammars. Analyzing this feature contributes to the general theory of subordination and complex clauses.

\subsection{Analysis of lexical meaning}

The domain of lexical semantics is very broad. Papers included in this volume focus mainly on two fundamental semantic relations: synonymy and polysemy. The analysis of lexical synonyms requires above all exposing their semantic properties and can be supplemented by diachronic data. In this manner, D. Dobrovol'skij and L. Pöppel study two pairs of synonyms that originated from the same semantic field, power: revolucija 'revolution' vs. perevorot 'coup', and mjatež 'revolt' vs. vosstanie 'uprising'. In order to differentiate between these terms, lexicographic information alone is not sufficient, and their distinctive features have been elucidated by comparing current contexts to the contexts of 1917. Like M. Makartsev's paper (see above), the study of this lexical class represents a fundamental basis for discourse analysis, in particular for political discourse, because it reveals linguistic strategies often deployed for manipulation.

Issues of polysemy discussed in this volume concern nouns, adjectives, and adverbs. V. Beliakov's study of lexical items in semi-phrasemes (this volume) reexamines combinations of two nouns, so-called "collocations", which are used to express a large quantity in Russian, such as kuča voprosov 'a heap of questions'. He distinguishes two classes of quantifying nouns that have different relationships with the metaphorical transfer. It is also to the description of metaphoric as well as metonymic patterns that T. Reznikova et al. (this volume) devote their paper, but this time, it is applied to the lexical field of quality in Russian. This is an experimental study introducing a new methodology that involves compiling a database of qualitative lexemes (adjectives, adverbs, predicatives). This database allows the authors to bring to light recurrent correlations between different parameters of qualitative lexemes as well as to draw more general conclusions on the lexical system functioning as a whole, such as "systemic organization" of vocabulary. This electronic treatment of lexicological data reveals that current theories of semantic changes need further elaboration, which encourages discussion on the universality of these phenomena from a cross-linguistic perspective.

Papers included in this volume explore a number of linguistic issues in Slavic languages, ranging from morphology to syntax and semantics. The volume assigns 
equal importance to each of them since the authors' differing approaches contribute to our understanding of the issues from a broad variety of angles.

\section{Acknowledgements}

We are grateful to the following scholars for their perceptive comments on papers in this volume at early stages: Christine Bonnot (Institute for Oriental languages, INALCO, Paris, France), Greville G. Corbett (Surrey University, United Kingdom), Paul Garde (AixMarseille University, France), Marguerite Guiraud-Weber (Aix- Marseille University, France), Steven Franks (Indiana University- Bloomington, USA), Frank Y. Gladney (University of Illinois at Urbana-Champaign, USA), Grigory Kreydlin (Russian University for Humanities, RGGU, Moscow, Russia), Vladimir Plungian (Institute for Linguistics, Moscow, Russia), Robert Roudet (University of Lyon III, France), Marek Świdziński (University of Warsaw, Poland), Maria Szupryczyńska (University of Toruń, Poland), Nicolas Tournadre (Aix-Marseille University, France), Hélène Włodarczyk (University Paris IV-Sorbonne, France), Daniel Weiss (Zurich University, Switzerland), Charles Zaremba (Aix-Marseille University, France).

Our thanks must also be extended to Werner Abraham and Elly van Gelderen, editors from John Benjamins Publishing Compagny for giving us the possibility to publish our volume in Studies in Language Companion Series. In addition, we would like to express our sincere gratitude to Cornelis (Kees) H.J. Vaes for his suggestions and patience in preparation of this publication. And finally, personal thanks to Irina Mikaelian, and especially to Natalia Partenheimer for their help with translating and editing various parts of the volume.

\section{References}

Babby, Leonard. 1980. Existential Sentences and Negation in Russian. Ann Arbor MI: Karoma. Birjulin, Leonid A. 1994. Semantika i sintaksis russkogo impersonala: Verba meteorogica i ix diatezy. München: Verlag Otto Sagner.

Boguslavskij, Igor' M. 1991. Lingvističeskij processor i lokativnye obstojatel'stva. Voprosy jazykoznanija 1: 69-78.

Comrie, Bernard. 1981. Language Universals and Linguistic Typology. Oxford: OUP.

Creissels, Denis. 1991. Approche des constructions asubjectales, improprement désignées comme impersonnelles. In L'impersonnel: M.canismes linguistiques et fonctionnement littéraire, Michel Maillard (ed.), 47-57. Grenoble: Ceditel.

Fortuin, Egbert L.J. 2000. Polysemy or Monosemy: Interpretation of the Imperative and the Dative-infinitive Construction in Russian. Amsterdam: Institute for Logic, Language and Computation. 
Franks, Steven. 1995. Parameters of Slavic Morphosyntax. Oxford: OUP.

Galkina-Fedoruk, Evdokija M. 1958. Bezličnye predloženija v sovremennom russkom jazyke. Moskva: MGU.

Georgieva, Valentina. 1969. K voprosu o granicax bezličnyx predloženij russkogo jazyka. Učenye zapiski Moskovskogo Gosudarstvennogo Pedagogičeskogo Instituta 341: 6368.

Georgieva, Valentina. 1980. Bezličnye predloženija. In Istoričeskaja grammatika russkogo jazyka, Viktor Ivanovič Borkovskij (ed.). Moskva: Nauka.

Guiraud-Weber, Marguerite. 1979. O sintaksičeskoj prirode konstrukcij tipa: 'V komnate paxnet jablokami'. Russian Linguistics 4: 291-301.

Guiraud-Weber, Marguerite. 1984. Les propositions sans nominatif en russe moderne. Paris: Institut d'.tudes Slaves.

Guiraud-Weber, Marguerite. 2003. Le sujet en russe. In Le sujet [Bibliothèque des Faits de Langues], 63-72. Paris: Ophrys.

Guiraud-Weber, Marguerite. 2003. Ešče raz o russkom genitive otricanija: Vzgljad so storony, Russian Linguistics 27: 363-384.

Guiraud-Weber, Marguerite \& Zaremba, Charles. 2007. Incidence de la négation sur les deux premiers actants de la phrase en polonais, russe et tchèque. In La négation [Travaux du Cercle linguistique d'Aix-en-Provence] Christian Touratier \& Charles Zaremba (eds), 49-67. Aix-en-Provence: Presses Universitaires de Provence.

Hausenblas, Karel. 1958. Vývoj předmĕtového genitivu v češtině. Praha: Nakladatelství ČSAV. Ivić, Milka. 1965. On the origin of the Russian sentence type: (Ego) zavalilo snegom. Die Welt der Slaven X(3-4): 317-321.

Ickovič, Viktor A. 1974. Očerki sintaksičeskoj normy. In Sintaksis i norma, Galina Aleksandrovna Zolotova (ed.), 43-106. Moskva: Nauka.

Keenan, Edward. 1976. Towards a universal definition of subject. In Subject and Topic, Charles N. Li (ed.), 305-333. New York NY: Academic Press.

Maillard, Michel. 1985. L'impersonnel français de "il" à "ça”. In Autour de l'impersonnel, Jacques Chocheyras et al. (eds), 51-118. Grenoble: Ellug.

Majsak, Timur A. 2005. Tipologija grammatikalizacii konstrukcij s glagolami dviženija $i$ glagolami pozicii. Moskva: Jazyki slavjanskix kul'tur.

Malchukov, Andrej \& Siewierska, Anna (eds). 2011. Impersonal Constructions: A Crosslinguistic Perspective [Studies in Language Companion Series 124]. Amsterdam: John Benjamins.

Maurice, Florence. 1996. Der modale Infinitiv in der modernen russichen Standardsprache. München: Verlag Otto Sagner.

Mrázek, Roman. 1964. Sintaksis russkogo tvoritel'nogo. Praha: Státní pedagogické nakladatelství.

Mrázek, Roman. 1990. Sravnitel'nyj sintaksis slavjanskix literaturnyx jazykov. Brno: Univerzita J.E. Purkynĕ.

Padučeva, Elena V. 1992. O semantičeskom podxode k sintaksisu i genitivnom sub"ekte glagola byt'. Russian Linguistics 16(1): 53-63.

Partee, Barbara H. \& Borschev, Vladimir B. 2007. Existential sentences, BE, and the genitive of negation in Russian. In Existence: Semantics and Syntax, Ileana Comorovski \& Klaus von Heusinger (eds), 147-190. Dordrecht: Springer.

Pisarkowa, Krystyna. 1984. Historia składni języka polskiego. Ossolineum: PAN.

Plungjan, Vladimir A. 2003. Obščaja morfologija. Vvedenie v problematiku. Moskva: Editorial URSS.

Švedova, Natalia Ju. (Ed.). 1964. Izmenenija v sisteme prostogo i osložnennogo predloženija $v$ 
russkom literaturnom jazyke XIX veka. Očerki po istoričeskoj grammatike russkogo literaturnogo jazyka XIX veka. Moskva: Nauka.

Testelec, Jakov G. 2001. Vvedenie v obščij sintaksis. Moskva: RGGU.

Veyrenc, Jacques. 1979. Les propositions infinitives en russe. Paris: Institut d'.tudes Slaves.

Vojvodić, Dojcil. 2007. Ob infinitivnyx predloženijax s sub"ektom v datel'nom padeže v russkom jazyke i ix.kvivalenty v serbskom i pol'skom. Zbornik Matice srpske za slavistiku 71-72: 557-581.

Weiss, Daniel. 1987. Polsko-niemieckie paralele w zakresie czasownik.w modalnych Sprachund Kulturkontakte im Polnischen, Gerd Hentschel \& Alek Pohl (eds), 131-156. München: Otto Sagner.

Weiss, Daniel. 1988. Konstrukcje typu: mieć (coś) do załatwienia, być do załatwienia oraz dać (coś) do załatwienia: Stopien ich sfrazeologizowania dawniej i dziś. In $Z$ problemów frazeologii polskiej i słowianskiej, Mieczysław Basaj \& D. Ryc (eds). Wrocław.

Weiss, Daniel. 1993. Infinitif et datif en polonais contemporain: Un couple malheureux? In Actes du VI colloque international de linguistique romane et slave, Stanisław Karolak (ed.), 443-487. Cracovie: WSP.

Wiemer, Björn. 1996. Analityczne passivum w języku rosyjskim i polskim. In Semantyka a konfrontacja językowa, Violetta Koseska-Toszewa \& Danuta Rytel-Kuc (eds). Warszawa: SOW.

Wolińska, Olga. 1978. Konstrukcje bezmianownikowe we wspöłczesnej polszczyźnie. Katowice: Uniwersytet Sląski.

Zolotova, Galina A. 1966. K razvitiju složno-padežnyx konstrukcij. In Razvitie sintaksisa sovremennogo russkogo jazyka, 147-173. Moskva.

Zolotova, Galina A. 1973. Očerk funkcional'nogo sintaksisa russkogo jazyka. Moskva: Nauka.

Žaža, Stanislav. 1978. K problematice negativních konstrukcí se slovesem esse v ruštině a v češtině. In Ceskoslovenské přednášky pro VIII mezinarodni sjezd slavistů v Záhřebu. Prague: Academia Praha.

Žaža, Stanislav. 1998. K jednomu typu českych a ruskych vět s funkčnim predikativem. Sbornik Praci Filozofické Fakulty Brněnské Univerzity, 89-92.

Žaža, Stanislav. 2002. Ešče raz k xarakteristike otricatel'nyx konstrukcij v russkom jazyke. Sborník Prací Filozofické Fakulty Brněnské Univerzity, 51-56. 